\title{
Decontamination and optimization study of hexavalent chromium on modified chicken feather using response surface methodology
}

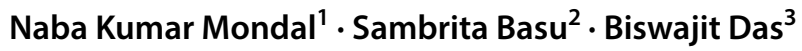 \\ Received: 17 September 2018 / Accepted: 12 March 2019 / Published online: 22 March 2019 \\ (c) The Author(s) 2019
}

\begin{abstract}
Present research highlighted the efficacy of alkali-treated $(1 \% \mathrm{NaOH})$ chicken feather toward removal of $\mathrm{Cr}(\mathrm{VI})$ from aqueous solution through batch study. Box-Behnken design (BBD) by response surface methodology was used to optimize the adsorption process. Kinetics and sorption isotherms have been determined considering the effect of initial metal concentration, adsorbent dose, contract time, and temperature. Batch sorbent data were fitted to various sorption models, and results indicate that $\mathrm{Cr}(\mathrm{VI})$ sorption process using alkali-treated chicken feathers followed the pseudo-second-order rate model, while sorption isotherms were described properly by both Langmuir $\left(R^{2}: 0.997\right)$ and Freundlich isotherms $\left(R^{2}: 0.979\right)$. Based on BBD design, the quadratic models were developed co-relating the adsorption variables to removal efficiency. Analysis of variance (ANOVA) was incorporated to judge the adequacy of model ( $F: 3484.72)$. Model predicted optimized conditions are initial concentration $5.64 \mathrm{mg} / \mathrm{L}$, adsorption dose $0.15 \mathrm{~g}$, contract time $29.60 \mathrm{~min}$, $\mathrm{pH} 1.06$ gave $88.9 \%$ removal efficiency. Sorption isotherms show that the experimental maximum sorption capacity of $\mathrm{Cr}(\mathrm{VI})$ was found to be $90.91 \mathrm{mg} / \mathrm{g}$ at $40{ }^{\circ} \mathrm{C}$ and $\mathrm{pH}$ 2. Therefore, present results demonstrate that alkali-treated chicken features should be regarded as a low-cost alternative for the removal of $\mathrm{Cr}(\mathrm{VI})$ from aqueous solution.
\end{abstract}

Keywords Chicken feather $\cdot$ Chromium $\cdot$ Kinetics $\cdot$ Isotherm $\cdot$ Regeneration

\section{Introduction}

Heavy metal pollution is now a growing concern because of its environmental contamination, non-biodegradable nature and potential carcinogenicity (Lunyera and Smith 2017; Dey and Mondal 2016). Due to non-degradable in nature of heavy metal, it can remain in all parts of the environment for prolong time (Srividya and Mohanty 2009). Among the various heavy metals, chromium is one of the most potent

Electronic supplementary material The online version of this article (https://doi.org/10.1007/s13201-019-0930-z) contains supplementary material, which is available to authorized users.

Naba Kumar Mondal

nkmenvbu@gmail.com

1 Environmental Chemistry Laboratory, Department of Environmental Science, The University of Burdwan, Bardhaman, West Bengal, India

2 Department of Biotechnology, The University of Burdwan, Bardhaman, West Bengal, India

3 Department of Chemistry, Kalna College, Kalna, West Bengal, India health hazards (Enniyaa et al. 2018). It exists in nature as trivalent and hexavalent form (Han et al. 2007). Hexavalent form of chromium (Cr VI) is more toxic and highly soluble than trivalent chromium (Khambhaty et al. 2009). The major source of $\mathrm{Cr}(\mathrm{VI})$ in the environment from electroplating metal finishing, pigment manufacturing, wood preservation (Park et al.2001; Gode and Pehlivan 2005) fertilizer, textile, photography discharge effluent and industrial wastewater (Shi et al. 2018).

Various problem such as severe diarrhea, eye and skin irritation, kidney defection and probable long carcinoma may be accelerated due to $\mathrm{Cr}(\mathrm{VI})$ concentration (Gupta et al. 2001). Therefore, there is tremendous need to remove such toxic substance from the aquatic medium. Several methods including physico-chemical treatment, reverse osmosis, evaporation and ion exchange have been employed for the purification of chromium containing waste water (Mclay and Reinhard 2000). However, above-mentioned methods have source limitation including generation of toxic sludge (Bai and Abraham 2001). Therefore, it is crucial to develop new eco-friendly, low-cost and effective techniques for its management. Biosorption of heavy metals by easily available biomaterials has been 
suggested as a potential alternative to the heavy metals from the Waste Water (Khambhaty et al. 2009).

Biosorption is a process in which biological agent can interact with the pollutants present in the aqueous medium through interaction with the surface of biosorbent via various interaction mechanism such as complexation, ion exchange, hydrogen bonding. (Mise and Rajamanya 2003). Moreover, Gupta et al. (2000) reported that naturally occurring biomass or spent biomass obtained from various fermentation industries can be effectively utilized. Research also highlighted that biotechnological exploitation of biosorption technology depends on the efficiency of regeneration of biosorption after metal desorption (Chhikara and Dhankhar 2008). Variety of low-cost adsorbents such as microorganisms, seaweed, clay minerals, groundwater treatment residuals have been reported for removal of heavy metals (Park et al. 2001; Das et al. 2013; Gupta and Ali 2004; Kan et al. 2017). But due to low biosorption capacity of the biosorbent, there is tremendous need of searching of other suitable adsorbent which may have higher adsorption capacity.

Feathers are non-abrasive, low density, good mechanical properties, insoluble in water and organic solvents and ambient temperatures, but solubility is enhanced with rise in temperature and addition of hydrophobic groups in the solvents (Kumari and Sobha 2015a, b). Many researchers used chicken feathers and wool keratin in making composites, due to its importance in textiles, cell cultivation (Tanabe et al. 2002; Tachibana et al. 2002) medicine (Tran and Mututuvari 2015). Birds feather consists of a fibrillar protein keratin made of different type of amino acids (cystine, lysine, proline, serine, etc.) with reactive functional side chains arranged in twisted $\beta$ sheets. This particular property could be used in environmental decontamination of heavy metal from aqueous solution.

The main objective of the present research is the preparation of adsorbent from chicken father and to utilize its potentiality for removal of hexavalent chromium from aqueous solution. Influence of adsorption parameters such as initial concentration, adsorbent dose, contract time, and $\mathrm{pH}$ on $\mathrm{Cr}(\mathrm{VI})$ removal was investigated. Box-Behnken design (BBD) by response Surface Methodology (RSM) using Design Expert Version 8.0.7.1 has been used. The experimental data were analyzed by fitting to a secondary polynomial model which again validated by analysis of variance (ANOVA) and lack-of-fit test.

\section{Materials and methods}

\section{Collection and preparation of chicken feather}

Chicken feathers were collected from a local poultry farm. At first, the feathers were washed with de-ionized water and dried at room temperature. Moreover, the feathers were again washed with acetone followed by treatment with $1 \%$ $\mathrm{NaOH}$ solution for 15 min and washed with distilled water. After that these feathers fibers are dried at room temperature.

\section{Metal solution preparation}

An aqueous stock solution of chromium(VI) ions was prepared using potassium dichromate by dissolving $0.2828 \mathrm{~g}$ potassium dichromate $\left(\mathrm{K}_{2} \mathrm{Cr}_{2} \mathrm{O}_{7}\right)$ in $250 \mathrm{~mL}$ of de-ionized water and diluted to $1 \mathrm{~L}$ in a volumetric flask with double distilled water. $\mathrm{pH}$ of the solution was adjusted using $0.1 \mathrm{~N} \mathrm{HCl}$ or $\mathrm{NaOH}$. Fresh dilutions were used for each sorption study.

\section{Batch experiments for chicken feather}

Batch experiments were carried out in 100-mL conical flask containing $25 \mathrm{mg} / \mathrm{L}$ of chromium solution. $0.15 \mathrm{~g}$ of chicken feather (dry biomass) and $25 \mathrm{mg} / \mathrm{L}$ of $50 \mathrm{~mL}$ chromium solution were taken in each $100-\mathrm{mL}$ conical flask. The desired $\mathrm{pH}$ of the respective solutions was maintained by adding $0.5(\mathrm{~N}) \mathrm{HNO}_{3}$ and/or $0.1(\mathrm{~N}) \mathrm{NaOH}$. The contact time for each solution was maintained for $30 \mathrm{~min}$. The stirring rate of the contact between solution and adsorbent maintained at $150 \mathrm{rpm}$ the particle size is $300 \mu \mathrm{m}$, and the temperature for all experiment except temperature variation fixed at $40{ }^{\circ} \mathrm{C}$.

Adsorption experiments were conducted in different batches where the $\mathrm{pH}$, adsorbent dose, stirring rate, contact time, particle size, initial chromium concentration and temperature were changed. In these experiments, parametric ranges were done by changing $\mathrm{pH}$ from $\mathrm{pH} 1$ to $\mathrm{pH} 10$, adsorbent dose: $0.005 \mathrm{~g}$ to $0.15 \mathrm{~g}$, stirring rate $150 \mathrm{rpm}$ to $350 \mathrm{rpm}$, contact time: 20-120 min, particle size $50 \mu \mathrm{m}$ to $300 \mu \mathrm{m}$, initial chromium concentration, $5-30 \mathrm{mg} / \mathrm{L}$ and finally changes of temperature ranges from 30 to $55^{\circ} \mathrm{C}$. Influence of various operating parameters was studied by varying one parameter at a time and keeping the others constant. This is a serial adsorption process where the best removal of chromium for a parameter can be screening out and fixed the value of that parameter followed the next experiment. Then the chromium was analyzed by spectrophotometer (PerkinElmer, Lambda 35).

\section{Metal analysis}

At the end of every step of adsorption, remaining metal concentration was measured through spectrophotometric method (Lambda 35) with a suitable color forming chemicals, 1-5 diphenyl carbazide. To estimate the percentage removal of chromium(VI) from aqueous solution, the following equation was used.

Percentage removal of $\mathrm{Cr}(\mathrm{VI})=\frac{c_{\text {initial }}-c_{\text {final }}}{c_{\text {initial }}} \times 100$
要

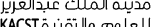
Springer 
where $C_{\text {initial }}$ and $C_{\text {final }}$ are the concentrations of $\mathrm{Cr}(\mathrm{VI})$ at the beginning and at the end of the adsorption process.

\section{Determination of $\mathrm{pHzpc}$}

The point of zero charge of the adsorbent was determined by the solid addition method (Mondal 2010). A $50 \mathrm{~mL}$ of $0.1 \mathrm{M}$ $\mathrm{KNO}_{3}$ solution transferred into a series of $100-\mathrm{mL}$ conical flask. The initial $\mathrm{pH}$ values of the solution were adjusted from 1.0 to 10.0 using $\mathrm{HNO}_{3}(0.05,0.1$ and $0.5 \mathrm{~N})$ or $0.1 \mathrm{~N}$ $\mathrm{KOH}$. Then fixed amount of chicken feather $(0.15 \mathrm{~g})$ was added to each conical flask and properly capped. The flasks were then placed into a constant temperature water bath cum shaker for $24 \mathrm{~h}$. The $\mathrm{pH}$ values of the supernatant liquid were noted after $24 \mathrm{~h}$.

\section{Experimental design}

Response surface methodology (RSM) was introduced by Box and Willson (1951) and later popularized by Montgomery. Basically RSM is a combination of statiscally experimental design and to optimized responses (output variable) that are influenced by several inputs variables (Chaudhary and Balomajumder 2014). It generates regression model equation and optimized conditions using minimum number of experimental rums according to experimental design (Cojocaru and Zakrzewska-Trznadel 2007).

Box-Behnken design is a spherical, rotatable, or nearly rotatable second-order design. It is based on three-level incomplete factorial design consisting center and middle points of the cube. The number of experimental points $(\mathrm{N})$ is defined by the expressions (1):

$N=2 K(K-1)+C_{0}$

where $K$ is the number of variables and $C_{0}$ is the number of center points. The variables used for modeling and statistically calculation are coded using Eq. (2) (Montgomery 2001):

$X_{i}=\frac{\alpha\left[2 x_{i}-\left(x_{\max }+x_{\min }\right)\right]}{x_{\max }-x_{\min }}$

where $X_{i}$ is the natural value of the $i$ th variable, $X_{i}$ is the dimension lets coded value of the $i$ th variable and $X_{\max }$ and $X_{\min }$ are the highest and the lowest limits of the $i$ th variable, respectively. The code \pm 1 has been used as independent variables, 0 is the center point, and the axial points are located at $( \pm \alpha)$.

\section{Modeling and statistical analysis}

The experimental data were analyzed and validated for predicted response $(Y)$. The percentage of removal is the main response which developed the model correlating the four variables using second-degree polynomial Eq. (3):

$Y=\beta_{\circ}+\sum_{i=1}^{k} \beta_{i} x_{i}+\sum_{i=1}^{k} \beta_{i i} x_{i}^{2} \sum_{i=1}^{k=1} \sum_{j=2}^{k} \beta_{i j} x_{i} x_{j}+\varepsilon$

where $Y$ is the predicted response, $x_{i}$ and $x_{j}$ are the input variables, $\beta_{\circ}$ is the intercept term, $\beta_{i}$ is the linear effect, $\beta_{i j}$ is the interaction effect, and $\varepsilon$ is a random error (Chattoraj et al. 2013). The fitness of regression model was evaluated by calculating coefficient of determination $\left(R^{2}\right)$ (Sadhukhan et al. 2014). The final model generated the responses in terms of graphical presentations of the parameter shown by 3D response Surface plots that gave their influence and an optimum parameter combination (Chaudhary and Balomajumder 2014).

\section{Results and discussion}

\section{Adsorbents characterization}

\section{Analysis of pHzpc}

The zero point charge of chicken feather showed 7.668 (Fig. 1). The charges on the surface of adsorbents depend on these pHzpc value below and above the pHzpc, the surface of the adsorbents changes to positive and negative charges, respectively. However, at the $\mathrm{pH}_{\text {ZPC }}$ point, adsorbent surface has no charge at all. As per the literature, chromium species present in different oxy-anionic forms

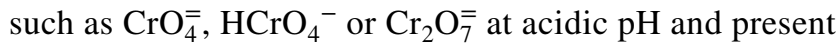
experiment suggests that all the three adsorbents showed maximum $\mathrm{Cr}(\mathrm{VI})$ removal at acidic $\mathrm{pH} 1$ and it is below the $\mathrm{pH}_{\mathrm{ZPC}}$ value. Therefore, it can be suggested that $\mathrm{Cr}(\mathrm{VI})$ adsorption is favorable when surface of the adsorbent is positive. Almost similar observation was reported by the earlier researchers (Das et al. 2013; Saha et al. 2013; Chhikara and Dhankhar 2008).

\section{SEM study}

Scanning electron microscopy has been used by many researchers for the characterization of the adsorbent as well as elucidation of the probable mechanism of biosorption (Srividya and Mohanty 2009). SEM micrographs obtained for native as well as chromium-loaded biosorbent are presented in Fig. 2a, b. SEM picture clearly revealed that chicken feather has huge surface area where $\mathrm{Cr}(\mathrm{VI})$ can bind through sulfur of protein associated in keratin structure. 


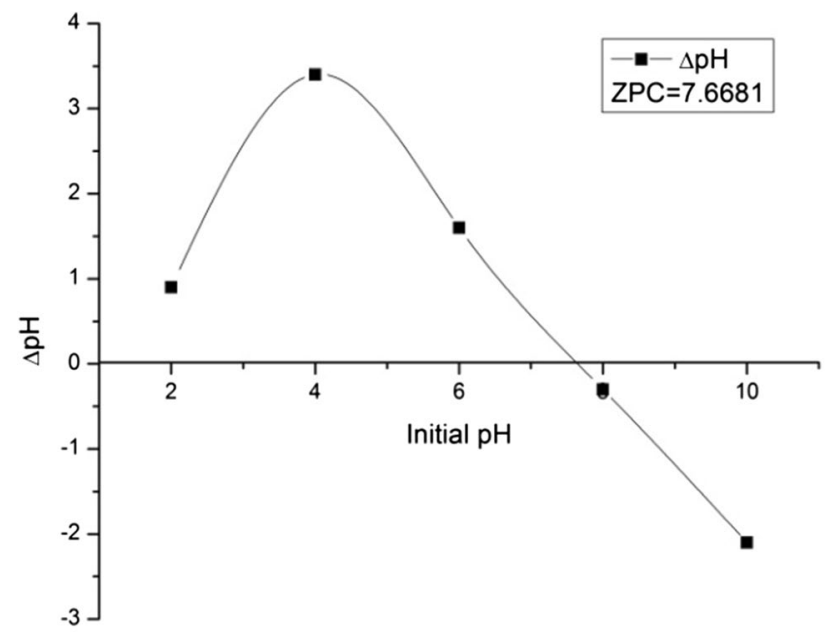

Fig. $1 \mathrm{P}^{\mathrm{H}} \mathrm{ZPc}$ of $\mathrm{Cr}(\mathrm{VI})$ by using chicken feather
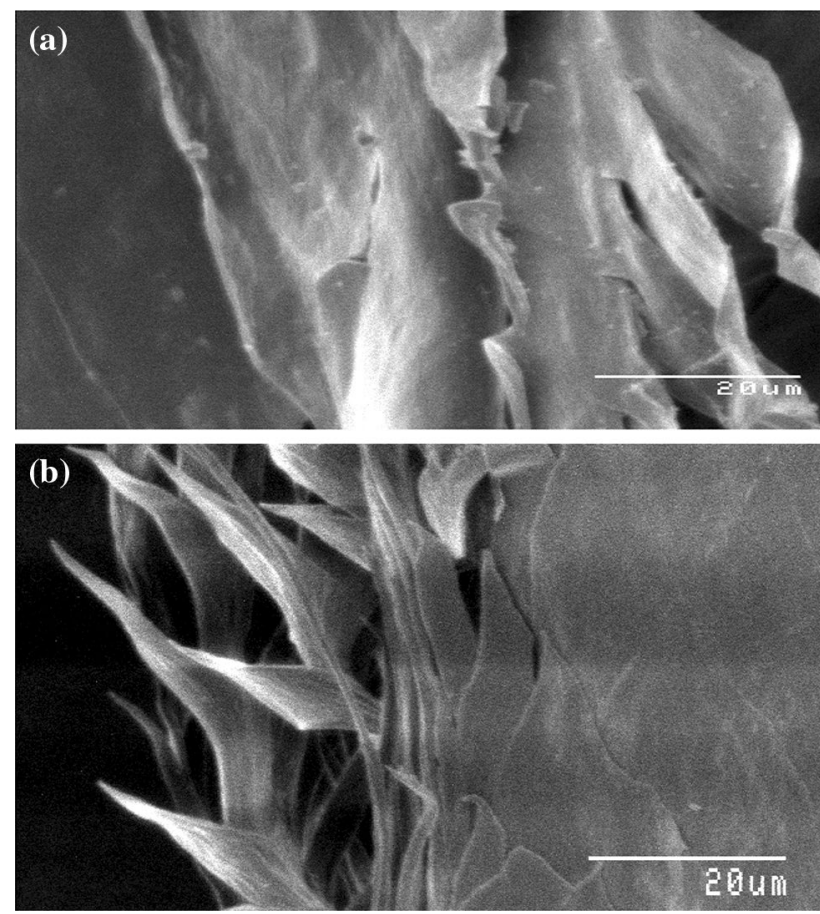

Fig. 2 a Chicken feather before $1500 \times$. b Chicken feather after 1500x

\section{FTIR study}

Before adsorption of heavy metal, chicken feather showed distinct IR peaks at $3259 \mathrm{~cm}^{-1}, 2966 \mathrm{~cm}^{-1}, 2877 \mathrm{~cm}^{-1}$, $2360 \mathrm{~cm}^{-1}, 2331 \mathrm{~cm}^{-1}, 1631 \mathrm{~cm}^{-1}, 1234 \mathrm{~cm}^{-1}$ and $1056 \mathrm{~cm}^{-1}$ (Fig. 3a). The sharp band at $3259 \mathrm{~cm}^{-1}$ corresponds to $\mathrm{N}-\mathrm{H}$ stretching vibration. Similarly, the peak at $1631 \mathrm{~cm}^{-1}$ is attributed the carbonyl $(-\mathrm{C}=\mathrm{O})$ of amide and another peak at $1234 \mathrm{~cm}^{-1}$ corresponds to amide $\mathrm{N}-\mathrm{H}$ stretching. Also the other characteristic peak at $1056 \mathrm{~cm}^{-1}$ corresponds to $\mathrm{S}=\mathrm{O}$ symmetric stretching mode of the cysteic acid, which is an intermediate in cysteine metabolism (Aguayo-Villarreal et al. 2011). However, after adsorption of $\mathrm{Cr}(\mathrm{VI})$, the entire peak position has been changed (Fig. 3b) which clearly indicates the possible interaction of $\mathrm{Cr}(\mathrm{VI})$ with the active centers of chicken feather. These peaks attributed the active functional groups such as alcoholic $-\mathrm{OH}, \mathrm{N}-\mathrm{H}$, carboxyl $-\mathrm{OH}$ stretching, $-\mathrm{C}-\mathrm{H},-\mathrm{P}-\mathrm{H}$ stretching, aromatic $>\mathrm{C}=\mathrm{C}<$, $>\mathrm{C}-\mathrm{O}$, and $>\mathrm{S}=\mathrm{O}$, respectively. However, after adsorption of $\mathrm{Cr}(\mathrm{VI})$, the entire peak position has been changed (Fig. 3b) which clearly indicates the possible interaction of $\mathrm{Cr}(\mathrm{VI})$ with the active centers of chicken feather. A hypothetical schematic diagram is presented in Fig. 4 which showed possible interaction between hexavalent chromium and active functional groups of chicken feather.

\section{Effect of initial concentration}

The variation of initial concentration of $\mathrm{Cr}(\mathrm{VI})$ was taken $5,10,15,20,25$, and $30 \mathrm{mg} / \mathrm{L}$ under constant $\mathrm{pH} 2$, adsorbent dose $0.01 \mathrm{~g}$, contact time $30 \mathrm{~min}$, temperature $40{ }^{\circ} \mathrm{C}$ and rpm 150. The graphical presentation on the effect of initial concentration is presented in Fig. 5. From Fig. 5, it is clear that percentage removal gradually increases with increasing initial concentration from 5 to $25 \mathrm{mg} / \mathrm{L}$. This is probably due to the fact that better mass transfer occurred from aqueous medium to solid adsorbent (Ahluwalia and Goyal 2010). Almost similar observations were reported in the earlier work (Saha et al. 2013).

\section{Effect of adsorbents dose}

The amount of chicken feather was increased from 0.005 to $0.15 \mathrm{~g}$ under constant $\mathrm{pH} 2$, initial concentration $25 \mathrm{mg} / \mathrm{L}$, constant time $30 \mathrm{~min}$ and temperature $40{ }^{\circ} \mathrm{C}$ (Fig. 6). It was observed that quantitative removal of the hexavalent chromium ion increases with increasing biosorbent dose and maximum removal was achieved by using $0.15 \mathrm{~g} / 50 \mathrm{~mL}$ chicken feather. The gradual increase in biosorption with increase in biosorbent dose is due to increase in surface area (Saha et al. 2013; Wang et al. 2008). However, further increase in adsorbent does not favor the removal of hexavalent chromium. This is attributed to the fact that the complete saturation of adsorbent surface and establishment of equilibrium between the ions already adsorbed and those remaining unadsorbed in the solution (Khambhaty et al. 2009). Moreover, previous literature highlighted that higher dose may hinder at the attachment sites of metal ions for removal of $\mathrm{Cr}(\mathrm{VI})$ by fish scale (Catla catla) (Zulkali et al. 2006). 
Fig. 3 a Chicken feather before adsorption. b Chicken feather after $\mathrm{Cr}(\mathrm{VI})$ removal
Fig. 4 A schematic diagram which shows possible interaction between $\mathrm{Cr}(\mathrm{VI})$ and active functional groups of chicken feather
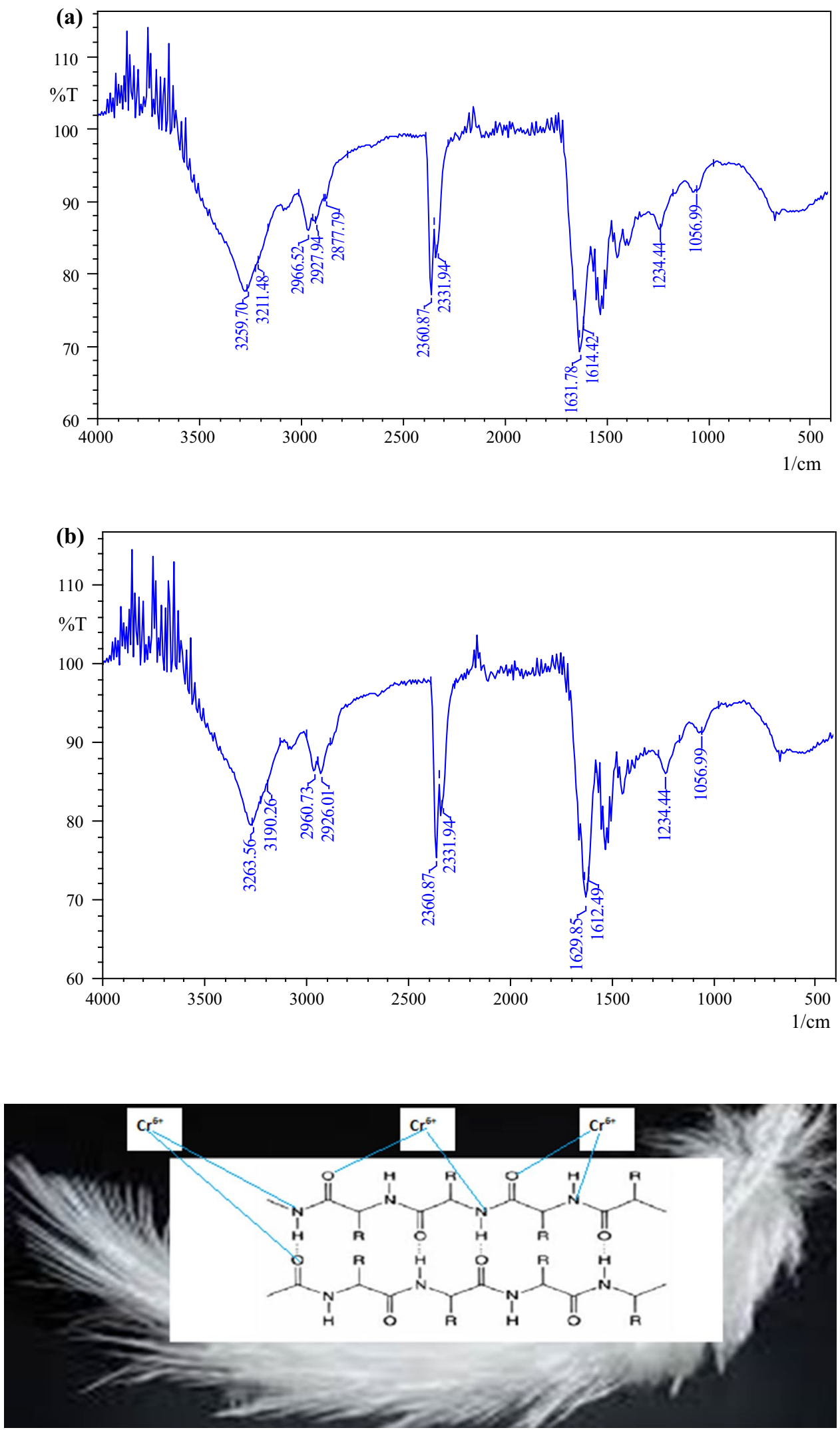
Fig. 5 Effect of initial concentration

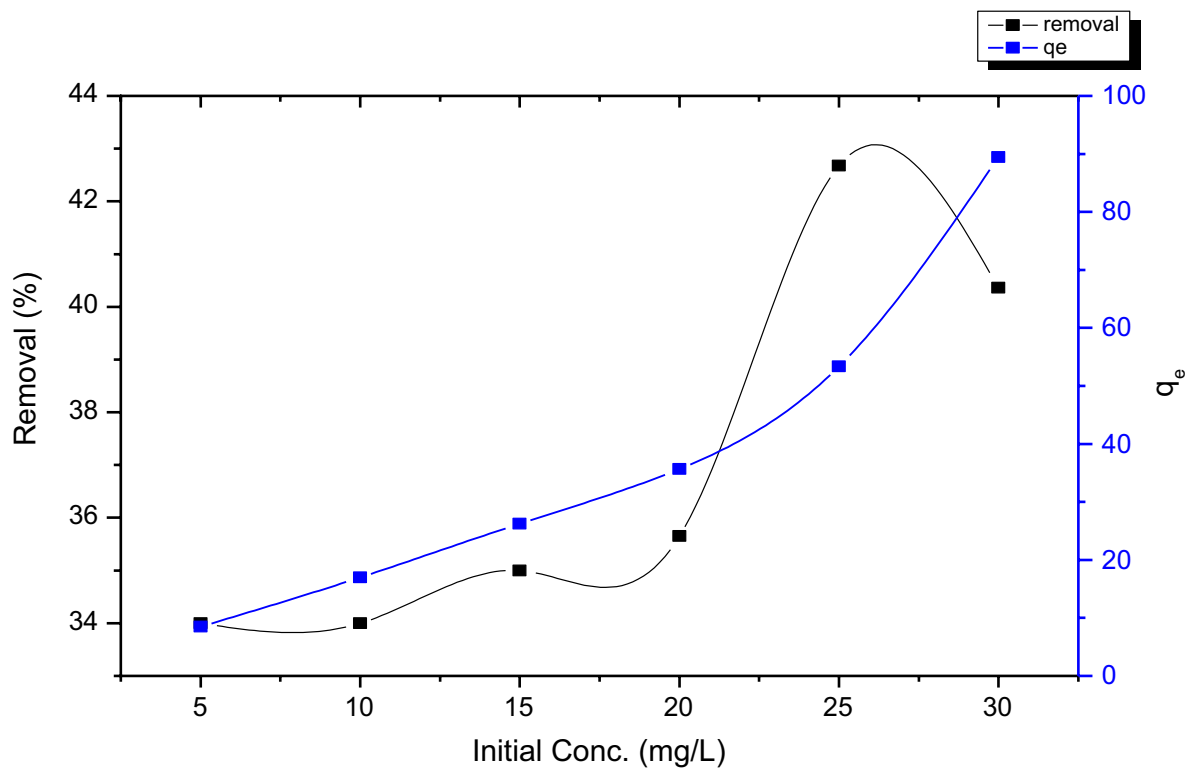

\section{Effect of contact time}

The uptake capacity and percentage of $\mathrm{Cr}(\mathrm{VI})$ removal was studied by varying the different time interval from $5 \mathrm{~min}$ to 35 min under constant $\mathrm{pH}(2)$, adsorbent dose ( $0.15 \mathrm{~g})$, initial concentration $(25 \mathrm{mg} / \mathrm{L})$, temperature $\left(40{ }^{\circ} \mathrm{C}\right)$. Figure 7 reveals that percentage of removal gradually increased with increasing contact time from 5 to $35 \mathrm{~min}$. The maximum removal $(54.16 \%)$ of $\mathrm{Cr}(\mathrm{VI})$ was recorded at $30 \mathrm{~min}$. Higher percentage of hexavalent chromium at higher contact time is possibly due to adsorbate get enough time to contact with adsorbent surface. Almost similar finding was reported by Srividya and Mohanty (2009).

\section{Effect of $p^{H}$}

The effect of $\mathrm{P}^{\mathrm{H}}$ on $\mathrm{Cr}(\mathrm{VI})$ uptake by chicken feather is presented in Fig. 8. Figure 8 clearly demonstrates that the $\mathrm{Cr}(\mathrm{VI})$ removal increases with decreasing the $\mathrm{pH}$ of the medium (Alemu et al. 2018). This is probably due to modification of surface in acid. The available chromium species in aqueous medium are $\mathrm{HCrO}_{4}{ }^{-}, \mathrm{CrO}_{4}{ }^{2-}$ or $\mathrm{C}_{2} \mathrm{O}_{7}{ }^{2-}$ depending on the hydrogen and hydroxyl ion concentration of the medium(Barrera-Diaz and Lugo-Lugo 2012). When the solution of $\mathrm{pH}$ is just below neutral $(\mathrm{pH}<7)$, the predominant species $\mathrm{HCrO}_{4}{ }^{-}$and $\mathrm{CrO}_{4}{ }^{-}$are available. Under these circumstances (acidic pH), the surface of chicken feather

Fig. 6 Effect of absorbents dose

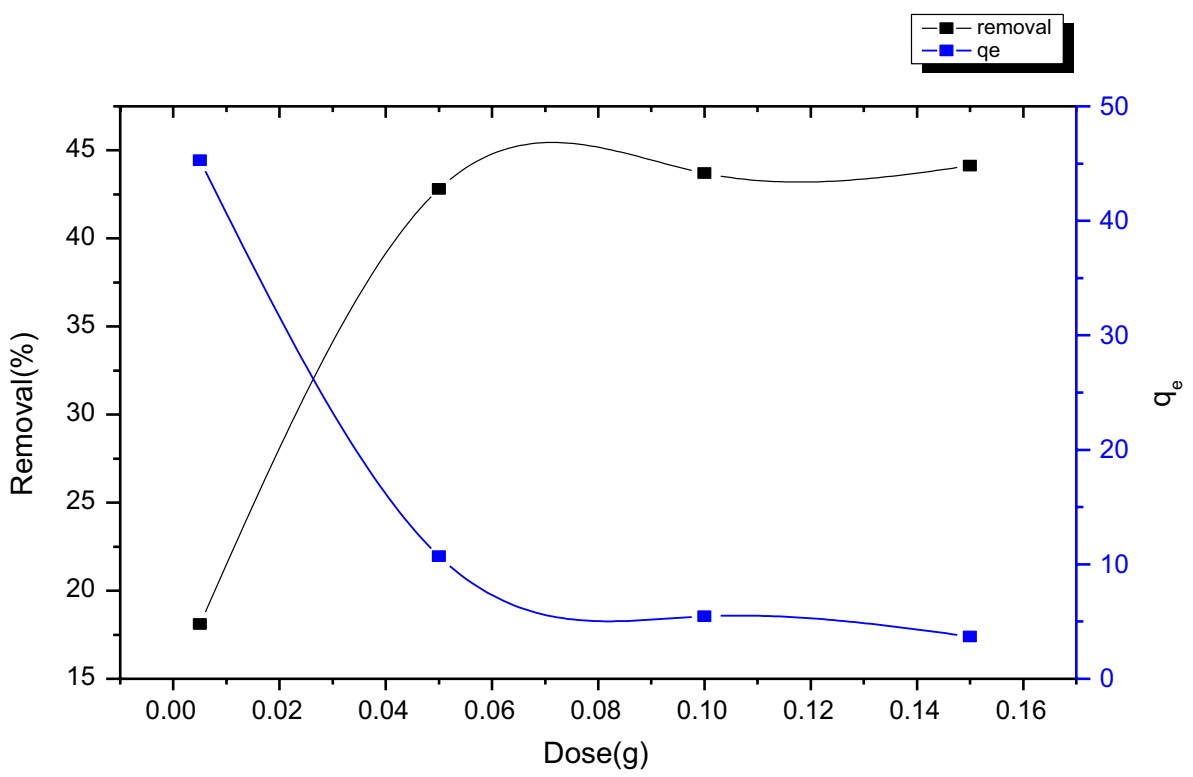


Fig. 7 Effect of contact time

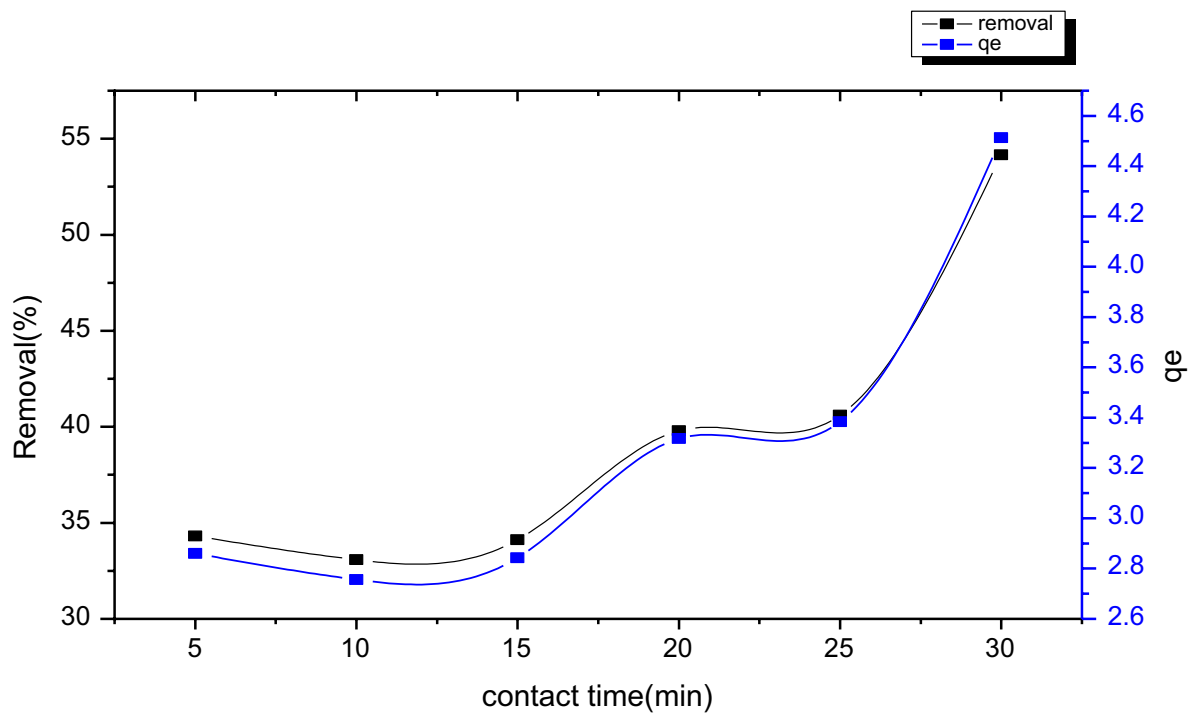

gets positive charge. The several functional groups present in keratin protein, especially peptide backbone, such as disulfide $(-\mathrm{S}-\mathrm{S})$, amino $\left(-\mathrm{NH}_{2}\right)$ and carboxylic acid $(-\mathrm{COOH})$ transform positive charges after protonation (Khosa et al. 2013). Therefore, the surface positive charge can easily attract negatively charged chromium species $\left(\mathrm{CrO}_{4}{ }^{2-}\right.$ and $\mathrm{HCrO}_{4}{ }^{-}$) through electrostatics attraction. Moreover, the groups on the surface of keratin biosorbents can hydrolyze water molecules of higher concentration of hydrogen ion and subsequently transform to a positive charge (Sun et al. 2009).

On the other hand, at higher $\mathrm{pH}$, the absorbent surface transforms to negatively charged and it does not support to attract the negatively charged species of chromium. Therefore, higher $\mathrm{pH}$ does not support higher removal of Cr(VI) (Dong et al. 2017; Kumar et al. 2013). Moreover, it is well established that biosorption of cation is favored at $\mathrm{P}^{\mathrm{H}}>\mathrm{P}^{\mathrm{H}} \mathrm{zpc}$, while the biosorption of anions is favored at $\mathrm{P}^{\mathrm{H}}<\mathrm{P}^{\mathrm{H}} \mathrm{zpc}$ (Osasona et al. 2015). Gupta and Babu (2009) also reported that the $\mathrm{Cr}(\mathrm{VI})$ can be reduced to $\mathrm{Cr}$ (III) and the possible reduction can be explained by the following reaction (4):

$\mathrm{HCrO}_{4-}+7 \mathrm{H}^{+}+3 e^{-} \rightarrow \mathrm{Cr}^{3+}+4 \mathrm{H}_{2} \mathrm{O}$

Therefore, this phenomenon obviously reduced the percentage of $\mathrm{Cr}(\mathrm{VI})$ removal in aqueous medium also.

\section{Effect of temperature}

$\mathrm{Cr}(\mathrm{VI})$ is removed from aqueous solution by varying the temperature from 30 to $60{ }^{\circ} \mathrm{C}$ under constant initial concentration (25 mg/L), $\mathrm{pH}(2)$, contact time (30 min), adsorbent dose $(0.15 \mathrm{~g})$ and shaking rate $(150 \mathrm{rpm})$ (Fig. 9$)$. Figure 9 clearly reveals that percentage of $\mathrm{Cr}(\mathrm{VI})$ removal increased from 54.16 to $68.16 \%$ when temperature increased from 30 to $50{ }^{\circ} \mathrm{C}$. This enhancement of adsorption with increasing temperature is probably due to diffusion of chromium (VI) through the external boundary layer and internal pores of chicken feather (Kumari and Sobha 2015a, b).

\section{Isotherm study of chicken feather}

The relationship between adsorbate and adsorbent was assessed by fitting the equilibrium data in isotherm models. The isotherms such as Langmuir, Freundlich, and D-R were used in this study. The entire isotherm constants and correlation coefficient values $\left(R^{2}\right)$ are presented in Table 1 . Table 1 suggests that adsorption of $\mathrm{Cr}(\mathrm{VI})$ by chicken feather is nicely fitted with Langmuir isotherm than Freundlich and D-R isotherm (Wang et al. 2015). This information is attributed to the fact that a homogenous monolayer mode of biosorption. Moreover, higher value of Freundlich isotherm constant, $K_{f}(1.078)$, means the sorption capacity of chicken feather is high. Earlier study (Al-Aseh et al. 2003) also reported that chemically treated chicken feather can be suitably used for removal of $\mathrm{Cu}^{2+}$ and $\mathrm{Zn}^{2+}$ from their solutions. The equilibrium data may be fitted with Freundlich constants $\left(K_{f}\right)$ with very high $R^{2}$ values. The Dubinin-Radushkevich (D-R) isotherm exhibited a poor fit which was reflected from low correlation coefficient value. Almost similar observation was reported by Sayed et al. (2005) for removal of heavy metals from industrial water using chicken feathers.

\section{Adsorption kinetics for chicken feather}

The biosorption capacity of chicken feather was evaluated at different time intervals at $25 \mathrm{mg} / \mathrm{L}$ of $\mathrm{Cr}(\mathrm{VI})$ with a biomass dose $(0.15 \mathrm{~g} / 50 \mathrm{~mL})$ and $\mathrm{pH} 2.0$. Various kinetics models like pseudo-first-order, pseudo-second-order and intraparticle diffusion models were applied, and the different constant parameters of kinetic equation are presented in

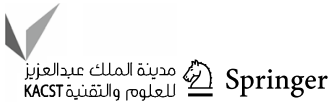


Fig. 8 Effect of $\mathrm{P}^{\mathrm{H}}$

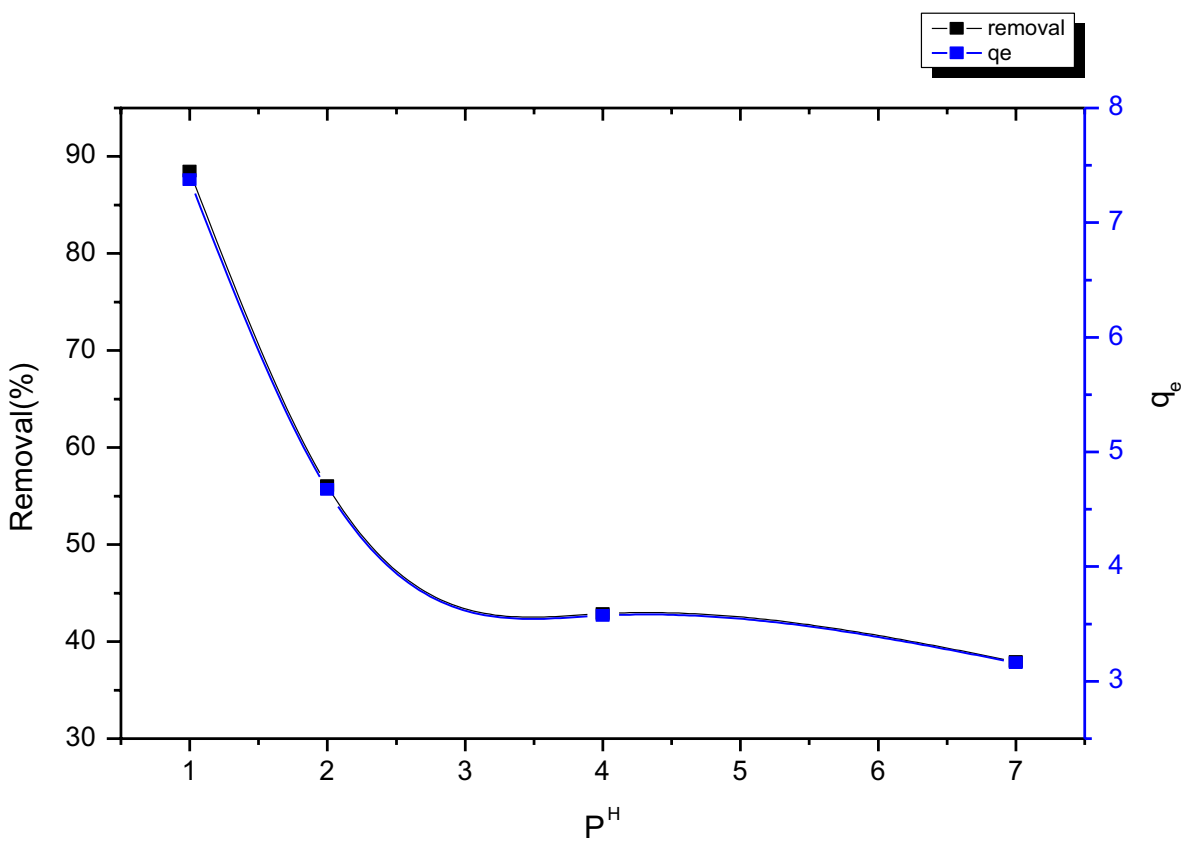

Table 1 Isotherm data for $\mathrm{Cr}(\mathrm{VI})$ adsorption using chicken feather

\begin{tabular}{llll}
\hline Adsorption isotherm & Equations & Parameters & Values \\
\hline Langmuir isotherm & $\frac{1}{q_{e}}=\frac{1}{q_{\max } K_{L} C_{e}}+\frac{1}{q_{\max }}$ & $q_{\max }$ & 90.91 \\
& $\log q_{e}=\log K_{F}+\frac{1}{n} \log C_{e}$ & $K_{L}$ & 42.73 \\
Freundlich isotherm & $\ln q_{e}=\ln q_{\max }-\frac{1}{2 E^{2}} *\left[R T \ln \left(1+\frac{1}{C_{e}}\right)^{2}\right]$ & $K_{F}(\mathrm{mg} / \mathrm{g})(\mathrm{L} / \mathrm{mg})^{1 / \mathrm{n}}$ & 1.078 \\
& & $q_{\max }$ & 4.739 \\
D-R isotherm & & $E(\mathrm{~kJ} / \mathrm{mol})$ & 11.34 \\
& & & 4.76 \\
\hline
\end{tabular}

Fig. 9 Effect of Temperature

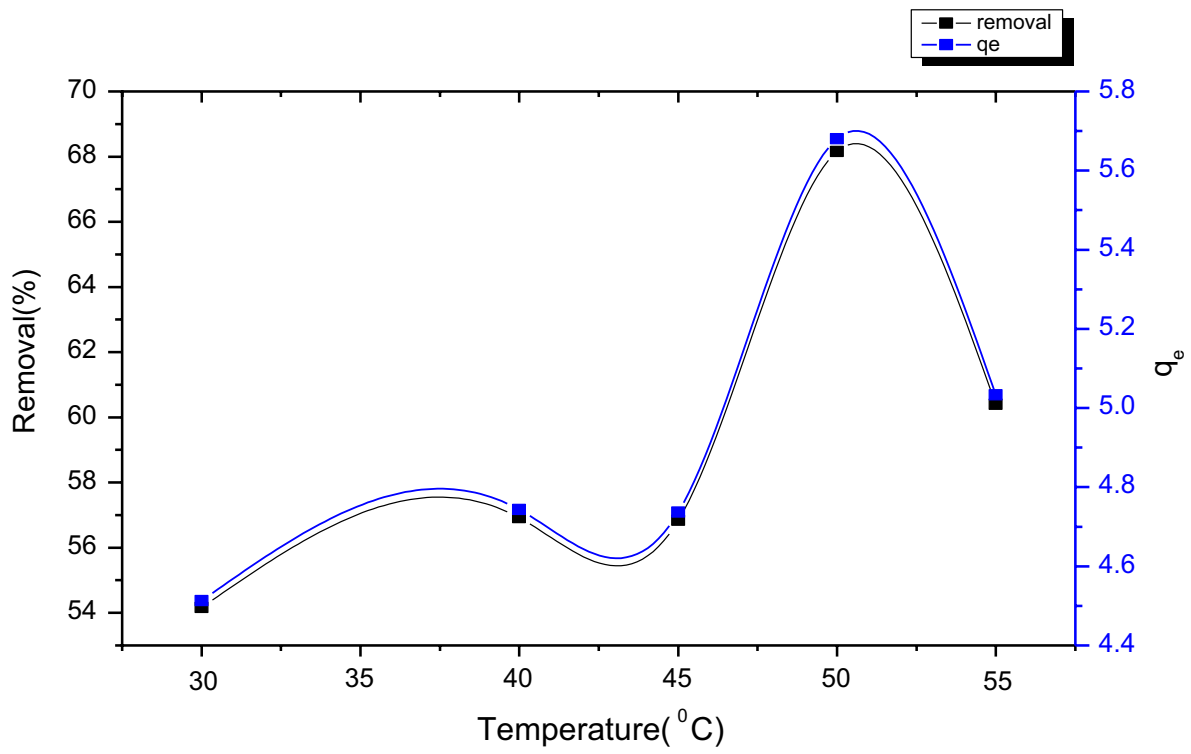


Table 2 Summary of parameters for various kinetic models by chicken feather

\begin{tabular}{lllll}
\hline Kinetics model & Equations & Parameters & Values & $R^{2}$ \\
\hline Pseudo-first order & $\log \left(q_{e}-q_{t}\right)=\log q_{e}-\frac{K_{1} t}{2.303}$ & $q_{e}(\mathrm{mg} / \mathrm{g})$ & 50.12 & 0.758 \\
& & $K_{1}\left(\mathrm{~min}^{-1}\right)$ & $1.755 \times 10^{2}$ & \\
Pseudo-second order & $\frac{t}{q_{t}}=\frac{1}{K_{2} q_{e}^{2}}+\frac{1}{q_{e}}$ & $q_{e}(\mathrm{mg} / \mathrm{g})$ & 0.279 & 0.978 \\
& & $K_{2}(\mathrm{~g} / \mathrm{mg} \mathrm{min})$ & 5.787 & \\
Intraparticle diffusion & $q_{t}=K_{D} t / 2+C$ & $K_{D}\left(\mathrm{~min}^{-1 / 2}\right)$ & 3.019 & 0.665 \\
& & $C$ & 5.405 & \\
\hline
\end{tabular}

Table 2. Kinetic results suggest that biosorption of $\mathrm{Cr}(\mathrm{VI})$ by chicken feather is nicely fitted with pseudo-second-order kinetics with very high correlation coefficient $\left(R^{2}=0.978\right)$. However, other kinetic equation such as pseudo-first-order and intraparticle diffusion is moderately fitted with experimental data. In previous literature, Aguayo-Villarreal et al. (2011) also reported the same results for adsorption of $\mathrm{Zn}^{2+}$ through batch and column studies using chicken feather as biosorbent. They also argued that pseudo-second-order model assumes two-side sorbate-sorbent interaction and that is why pseudo-second-order model is suitable for bivalent metal ions.

\section{Thermodynamic study for chicken feather}

The thermodynamic parameters for the obtained equilibrium data on temperature variation by the use of Eqs. (5-6) were evaluated. The equilibrium constant $K_{c}$ was calculated based of $C_{\mathrm{Ae}}$ and $C_{\mathrm{e}}$ values:

$K_{c}=\frac{C_{\mathrm{Ae}}}{C_{\mathrm{e}}}$

where $C_{\mathrm{Ae}}$ indicates adsorption in $\mathrm{mg} / \mathrm{L}$ at equilibrium and $C_{\mathrm{e}}$ is the equilibrium concentration of the metal in $\mathrm{mg} / \mathrm{L}$. The respective values of other thermodynamic parameters such as $\Delta H^{\circ}$ and $\Delta S^{\circ}$ were obtained from the slope and interpret of the plot of $\log K_{c}$ against $1 / T$ (Eq. 6) revealed the values of free energy $\left(\Delta G^{\circ}\right)$ at different temperatures were obtained using Eq. 8.

$\log K_{c}=\frac{\Delta S^{0}}{2.303 R T}-\frac{\Delta H^{0}}{2.303 R T}$

where $T$ is the temperature in Kelvin and $R$ is the gas constant $(\mathrm{kJ} / \mathrm{mol} \mathrm{K})$.

The entire results for the thermodynamic parameters are presented in Table 3. From Table 3 it is clear that both $\Delta H^{\circ}$ and $\Delta S^{\circ}$ are positive. The positive value of $\Delta H^{\circ}$ for $\operatorname{Cr}(\mathrm{VI})$ removal by chicken feather confirms that the adsorption process is endothermic in nature and positive $\Delta S^{\circ}$ indicates the adsorption process is spontaneous. However, the spontaneity
Table 3 Thermodynamics parameters for adsorption of $\mathrm{Cr}(\mathrm{VI})$ by chicken feather

\begin{tabular}{llll}
\hline $\begin{array}{l}\text { Temperature } \\
(\mathrm{K})\end{array}$ & $\Delta G^{\circ}(\mathrm{kJ} / \mathrm{mol})$ & $\Delta H^{\circ}(\mathrm{kJ} / \mathrm{mol})$ & $\Delta S^{\circ}(\mathrm{kJ} / \mathrm{mol})$ \\
\hline 303 & -420.216 & & \\
313 & -725.165 & 19.15 & 57.44 \\
318 & -726.246 & & \\
323 & -2044.332 & & \\
328 & -1151.517 & & \\
\hline
\end{tabular}

Table 4 Variables coded for adsorption parameters for analysis by BBD

\begin{tabular}{llllll}
\hline S1. nos. & Variables & Factors & \multicolumn{2}{l}{ Levels } & \\
\cline { 3 - 6 } & & & -1 & 0 & +1 \\
\hline 1. & A & Initial conc. $(\mathrm{mg} / \mathrm{L})$ & 5 & 20 & 30 \\
2. & $\mathrm{~B}$ & Adsorbent dose $(\mathrm{g})$ & 0.005 & 0.08 & 0.15 \\
3. & $\mathrm{C}$ & Contact time (min) & 5 & 20 & 40 \\
4. & $\mathrm{D}$ & $\mathrm{pH}$ & 2 & 6 & 10 \\
\hline
\end{tabular}

of chromium adsorption is also supported by the free energy value at different temperature (Table 3), according to Eq. (7):

$\Delta G^{0}=-R T \ln K_{c}$

Recently, Enniyaa et al. (2018) reported the same variation of free energy with temperature for removal of $\mathrm{Cr}(\mathrm{VI})$ by activated carbon prepared from apple peel.

\section{Second-order polynomial equation}

The variables coded for adsorption parameters for analysis by BBD and their range are tabulated in Table 4 . The design matrix consisting 30 sets of experimental conditions in coded terms along with their values for the responses are given in Table Supp 1. The experimental results revealed that the percentage of $\mathrm{Cr}(\mathrm{VI})$ removal ranges from 46.80 to $88.89 \%$. The design indicated the second-order polynomial model for the selected on the basis of the sequential model 
sum of squares where the additional terms were significant, and the models were not aliased (Table Supp 2). On the other hand, model summary statistics clearly demonstrated that adjusted and predicted $R^{2}$ is very close to each other (Table Supp 3). Moreover, the quality of the model was justified on the basis of $R^{2}$ and standard deviation values (Table Supp 4).

The ANOVA analysis results are depicted in Table 5. The model predicted $\mathrm{F}$ value is very high (3484) with a probability value $p<0.0001$ which implies that the model is significant. The adequate precision ratio is 189.72 which validates the model indicating high signal-to-noise ratio. The lack-offit analysis was found to be non-significant $(p=0.999)$ which indicates that linear model could be valid. Moreover, a high value of adjusted determination coefficient $\left(R^{2}=0.999\right)$ was estimated. This result means that $99.94 \%$ of the total variation on $\mathrm{Cr}(\mathrm{VI})$ biosorption data can be described by the selected model. Moreover, the $p$ values for the individual parameter, interaction and square terms such as A, B, C, $\mathrm{AB}, \mathrm{AD}, \mathrm{BC}, \mathrm{BD}, \mathrm{CD}, \mathrm{A}^{2}, \mathrm{~B}^{2}$ and $\mathrm{D}^{2}$ were highly significant and other terms such as $\mathrm{D}, \mathrm{AC}$ and $\mathrm{C}^{2}$ are not significant $(p>0.05)$. The predicated response was calculated in terms of second-order polynomial equation with single, interactional and quadratic terms as shown in the following Eq. (8):

$$
\begin{aligned}
\operatorname{Removal}(\%)= & +58.17+1.11 * A+1.42 * B \\
& +0.18 * C-15.43 * D-3.72 * A * B \\
& -0.29 * A * C-2.19 * A * D+0.17 * B * C \\
& -0.61 * B * D-1.36 * C * D \\
& +3.04 * A 2+4.36 * B^{2}-0.27 * C^{2}+5.12 * D^{2}
\end{aligned}
$$

In Eq. (8), A, B, C and D are independent singular factors, whereas $\mathrm{AB}, \mathrm{AC}, \mathrm{AD}, \mathrm{BC}, \mathrm{BD}$, and $\mathrm{CD}$ are interaction factors, and the quadratic terms include $\mathrm{A}^{2}, \mathrm{~B}^{2}, \mathrm{C}^{2}$ and $\mathrm{D}^{2}$.

\section{Response surface and diagnostic plot}

The experimental data were fitted in the RSM model and analyzed to establish the relation between normal and residual and actual and predicted values (Fig. 10a, b). Figure $10 \mathrm{a}, \mathrm{b}$ clearly demonstrates that all the data points are very close to the straight line indicating the proposed quadratic model could be a useful one for predicting response

\begin{tabular}{|c|c|c|c|c|c|}
\hline Source & Sum of squares & $d f$ & Mean square & $F$ value & $P$ value Prob $>F$ \\
\hline Model & 4643.22 & 14 & 331.66 & 3484.72 & $<0.0001$ \\
\hline A-initial concentration & 15.61 & 1 & 15.61 & 163.99 & $<0.0001$ \\
\hline$B$-adsorbent dose & 23.09 & 1 & 23.09 & 242.60 & $<0.0001$ \\
\hline$C-p H$ & 3480.77 & 1 & 3480.77 & 36572.33 & $<0.0001$ \\
\hline D-contact time & 0.28 & 1 & 0.28 & 2.98 & 0.1064 \\
\hline$A B$ & 65.99 & 1 & 65.99 & 693.35 & $<0.0001$ \\
\hline$A C$ & 0.35 & 1 & 0.35 & 3.62 & 0.0777 \\
\hline$A D$ & 30.30 & 1 & 30.30 & 318.37 & $<0.0001$ \\
\hline$B C$ & 0.092 & 1 & 0.092 & 0.96 & 0.3433 \\
\hline$B D$ & 1.94 & 1 & 1.94 & 20.38 & 0.0005 \\
\hline$C D$ & 8.97 & 1 & 8.97 & 94.20 & $<0.0001$ \\
\hline$A^{2}$ & 46.60 & 1 & 46.60 & 489.65 & $<0.0001$ \\
\hline$B^{2}$ & 93.85 & 1 & 93.85 & 986.11 & $<0.0001$ \\
\hline$C^{2}$ & 0.37 & 1 & 0.37 & 3.92 & 0.0677 \\
\hline$D^{2}$ & 136.64 & 1 & 136.64 & 1435.68 & $<0.0001$ \\
\hline Residual & 1.33 & 14 & 0.095 & & \\
\hline Lack of fit & 0.20 & 11 & 0.018 & 0.047 & 0.9999 not significant \\
\hline Pure error & 1.13 & 3 & 0.38 & & \\
\hline Cor total & 4644.55 & 28 & & & \\
\hline Std. dev. & 0.31 & & & $R$-Squared & 0.9997 \\
\hline Mean & 66.56 & & Adj $R$-squared & 0.9994 & \\
\hline C.V. $\%$ & 0.46 & & & Pred R-squared & 0.9991 \\
\hline PRESS & 4.20 & Adeq precision & 189.722 & & \\
\hline
\end{tabular}
over independent input data points (Mondal et al. 2017). On the other hand, 3D-response surface plot gives the graphical representation of interactive effects of individual parameter

Table 5 Analysis of variance (ANOVA), regression coefficient estimate and test of significance for Cr(VI) removal on Aspergillus niger 


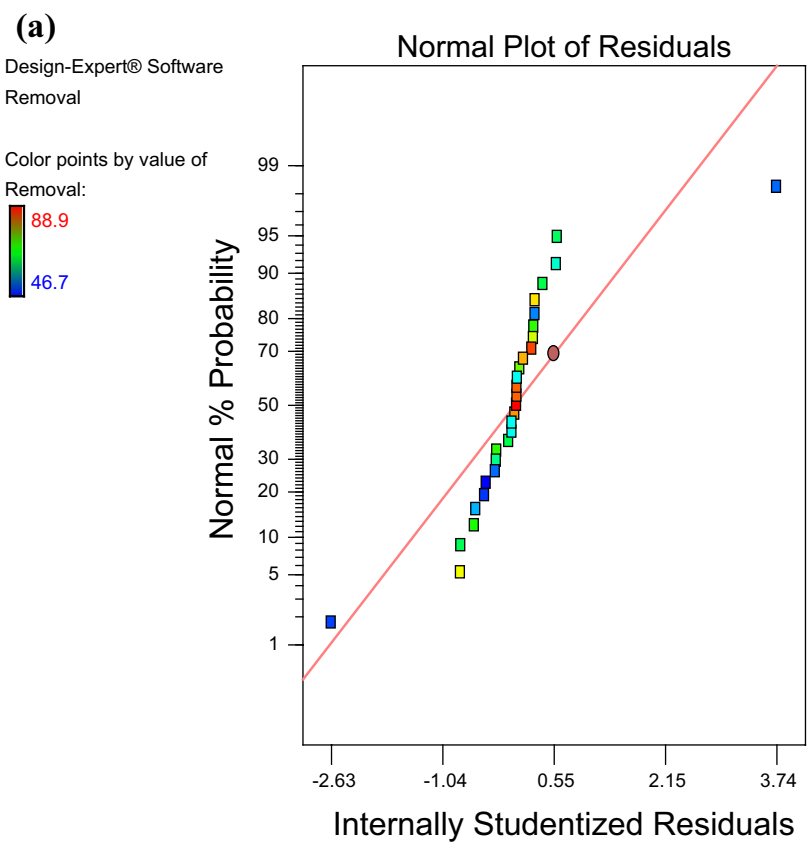

(b)

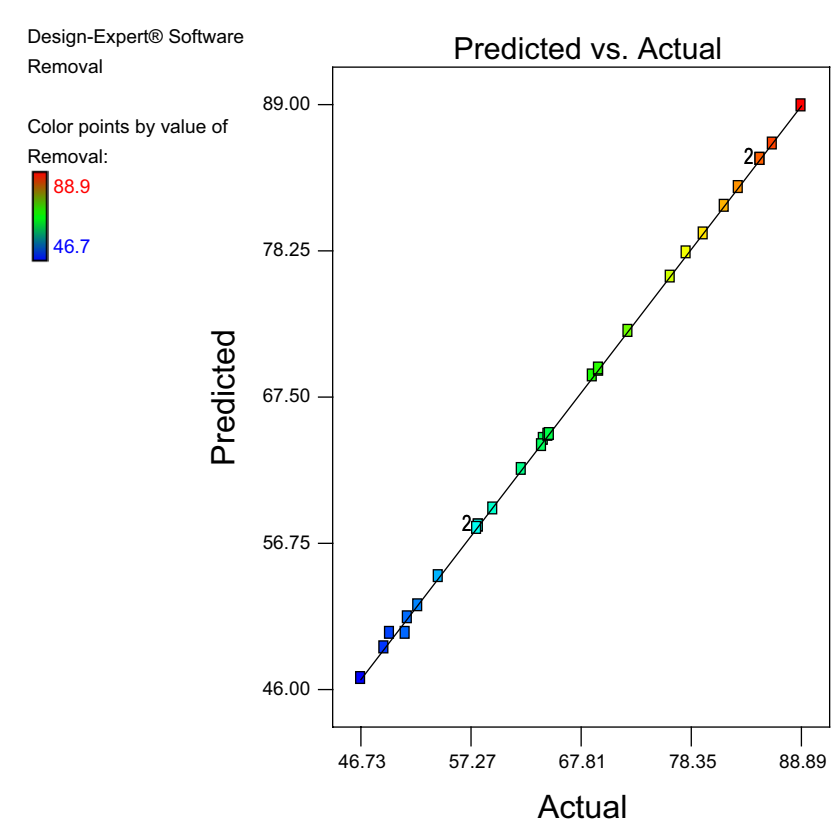

Fig. 10 a Plot of normal \% probability versus residual error, $\mathbf{b}$ comparison between the actual values and the predicted values of RSM model for adsorption of $\mathrm{Cr}(\mathrm{VI})$

over the response (Fig. 11a-f). Similarly, desirability study clearly represents the optimization of various operating parameters (e.g., initial concentration; adsorbent dose; contact time and $\mathrm{pH}$ ) with desirability 1.0 for $89.1 \%$ removal of Cr(VI) (Fig. 12).

\section{Comparative study with other published work}

A comparative study has been done for judging the performance of the present adsorbent with the previously published adsorbents (Table 6). Table 6 highlights that previous researchers have been tried with chicken feather or the processed product of chicken feather for removal of many metals such as $\mathrm{Pb}^{2+}, \mathrm{Au}^{2+}, \mathrm{Pt}^{2+}, \mathrm{Zn}^{2+}, \mathrm{Cu}^{2+}$ and $\mathrm{Cr}^{6+}$ (Sekimoto et al. 2013; Gao et al. 2014; Aguayo-Villarreal et al. 2011). Among the various forms of chicken feather, maximum adsorption of metals ions was recorded for chicken feather only or alkali-treated chicken feature. In this present work, alkali-treated chicken feather showed adsorption capacity $90.91 \mathrm{mg} / \mathrm{g}$ and it is much higher than other reported chicken feather-based adsorbent except chicken feather powder which removes $60-160 \mathrm{mg} / \mathrm{g} \mathrm{Au}^{2+}$ in acidic medium $(\mathrm{pH}$ 1-3). Moreover, it is also highlighted that acidic medium (ranges from 1 to $6 \mathrm{pH}$ ) is suitable for removing any metal.
However, only one report (Jin et al. 2013) indicates that $\mathrm{Cu}^{2+}$ can be removed (41\%) in alkali medium ( $\mathrm{pH} 11)$ by nonwoven mesh-based duck feather.

\section{Conclusion}

The present study was highlighted the use of response surface methodology as an experimental design tool to explain the main operating variables and their interaction on the removal of $\mathrm{Cr}(\mathrm{VI})$ by using chemically treated chicken feather. For this purpose, the effect of four main operating variables such as initial concentration, adsorption dose, contact time and $\mathrm{pH}$ were evaluated. The results obtained for the removal of $\mathrm{Cr}(\mathrm{VI})$ were severally affected by all the mentioned operating variables. An optimum condition for $\mathrm{Cr}(\mathrm{VI})$ uptake of $90.91 \mathrm{mg} / \mathrm{g}$ at $40 \mathrm{C}$ was achieved at initial concentration $5.64 \mathrm{mg} / \mathrm{L}$, adsorption dose $0.15 \mathrm{~g} / 50 \mathrm{~mL}$, contact time $20.60 \mathrm{~min}$ and $\mathrm{pH} 1.06$. According to ANOVA results, the model presents high $R^{2}$ value of $99.97 \%$ for $\operatorname{Cr}(\mathrm{VI})$ removal efficiency which indicates the accuracy of the polynomial model. Moreover, the isotherm and kinetic study revealed the Langmuir and pseudo-second-order kinetic models are nicely fitted with high regression coefficient. 
(a)

Design-Expert@ Softw are

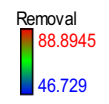

$\mathrm{X} 1=\mathrm{A}$ : initial concentration $\mathrm{X} 2$ = B: adsorbent dose

Actual Factors act time $=17.50$ C: contact time
D: $P H=4.00$

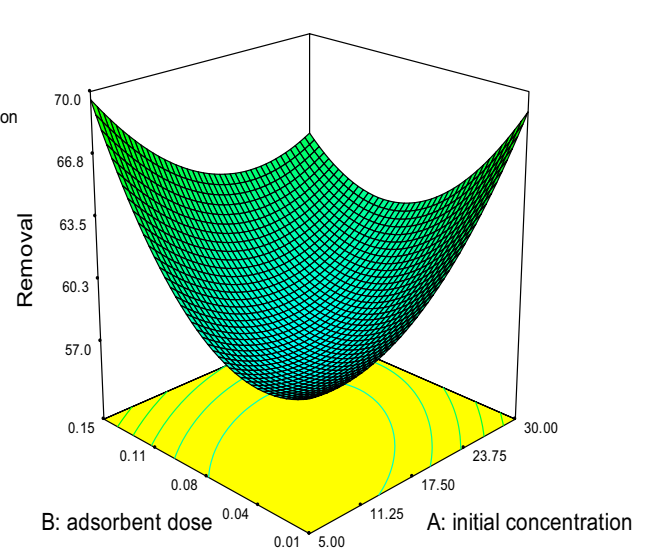

(c)

Design-Expert@ Softw are

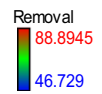

$\mathrm{X} 1=\mathrm{A}$ : initial concentration $\mathrm{X} 2=\mathrm{D}: \mathrm{PH}$

Actual Factors B: adsorbent dose $=0$ : contact time $=17.50$

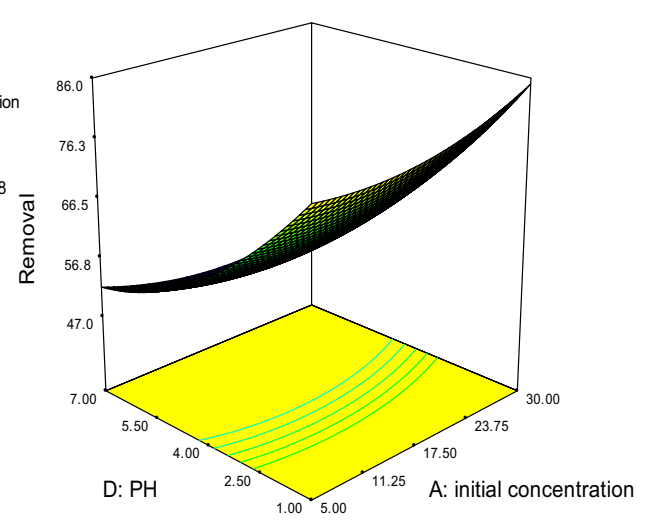

(e)

Design-Expert@ Softw are

\section{Removal
$\mid \begin{aligned} & 88.8945 \\ & 46.729\end{aligned}$}

$\mathrm{X} 1=\mathrm{B}$ : adsorbent dose $\mathrm{X} 2=\mathrm{D}: \mathrm{PH}$

\section{Actual Factors}

A: initial concentration $=17.50$ C: contact time $=17.50$

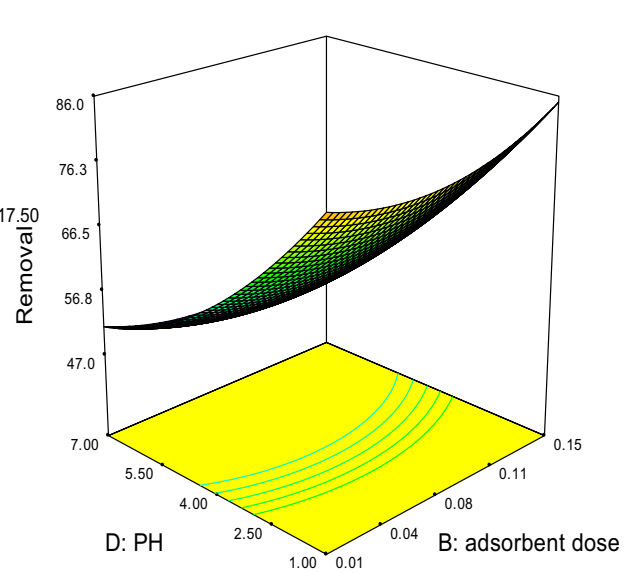

(b)

Design-Expert@ Softw are

Removal
$\mathbf{8} 8.8945$
46.729

$\mathrm{X} 1=\mathrm{A}$ : initial concentration $X 1=A:$ initial concent
$X 2$

Actual Factors

B: adsorbent dose $=0.08$ D: $\mathrm{PH}=4.00$

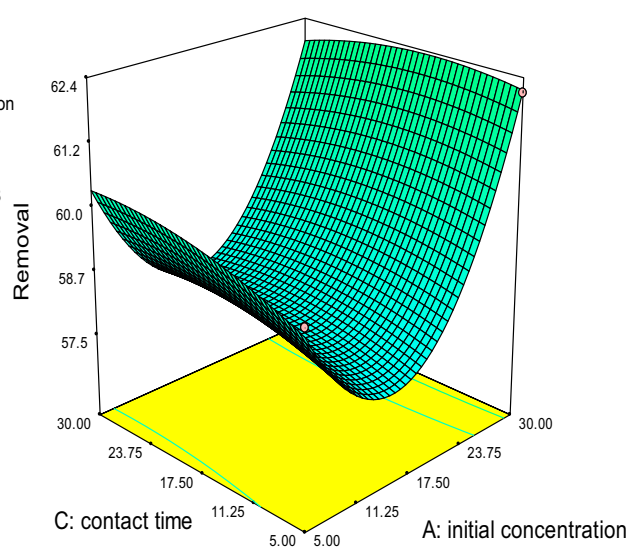

(d)

Design-Expert@ Softw are

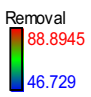

$\mathrm{X} 1$ = B: adsorbent dose $\mathrm{X} 2=\mathrm{C}$ : contact time

Actual Factors

A: initial concentration $=17.50$

D: $\mathrm{PH}=4.00$

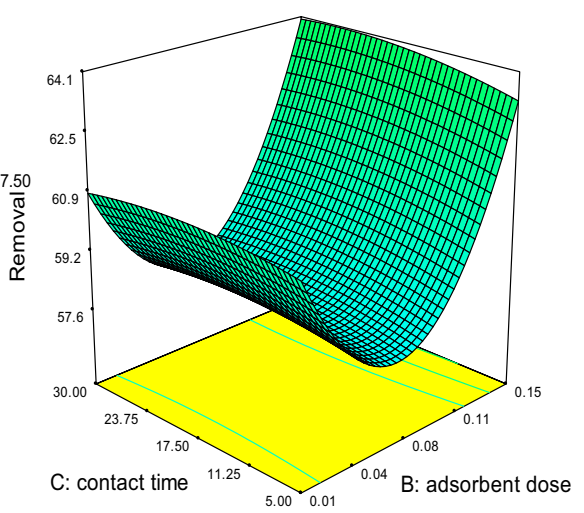

(f)

Design-Expert@ Softw are

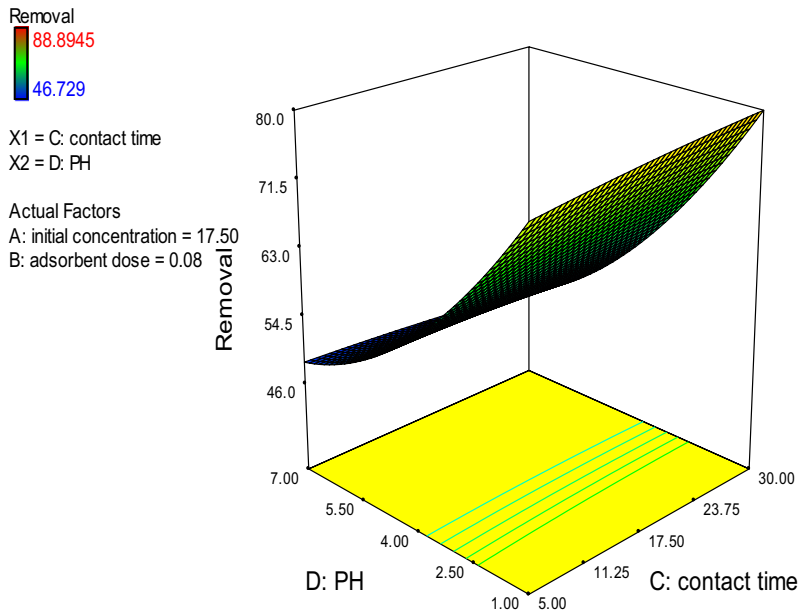

Fig. 11 a-f Response surface plots showing the effect of independent variables on $\mathrm{Cr}(\mathrm{VI})$ adsorption onto chicken feather 
Fig. 12 Desirability ramp for numerical optimization of four selected goals

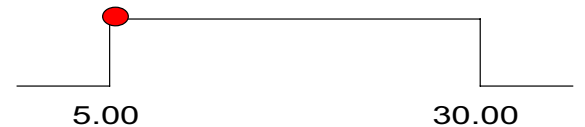

30.00

0.01

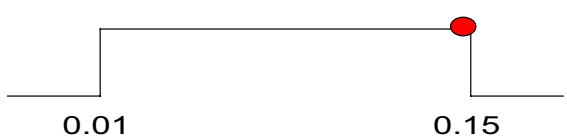

initial concentration $=5.64$

adsorbent dose $=0.15$
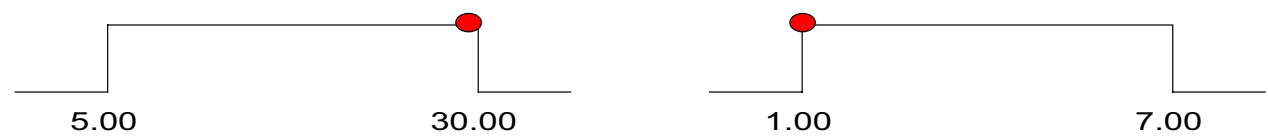

contact time $=29.60$

$\mathrm{PH}=1.06$

Desirability $=1.000$

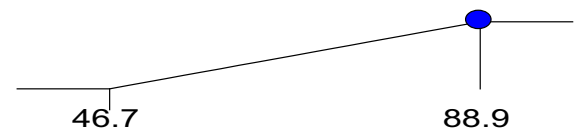

Removal $=89.1$
Table 6 Biosorption of $\mathrm{Cr}(\mathrm{VI})$ ions by different biosorbents

\begin{tabular}{lllll}
\hline Biosorbent & $\begin{array}{l}\text { Biosorp- } \\
\text { tion capacity } \\
(\mathrm{mg} / \mathrm{g})\end{array}$ & Metal & $\mathrm{pH}$ & References \\
\hline Poultry feather fiber & $0.8-8.3$ & $\mathrm{~Pb}^{2+}$ & $2-5$ & de la Rosa et al. (2008a, b) \\
Chicken feather particle & $100 \%$ & $\mathrm{Zn}^{2+}$ & $3-5$ & Jin et al. (2013) \\
Chicken feather particle treated with $\mathrm{NaOH}$ & $100 \%$ & $\mathrm{Cu}^{2+}$ & - & Sekimoto et al. (2013) \\
& $100 \%$ & $\mathrm{Zn}^{2+}$ & & \\
Colloidal keratin solution & 43.3 & $\mathrm{~Pb}^{2+}$ & 5 & Zhang et al. (2018) \\
Chicken feather treated with epichlorohydrin & $90 \%$ & $\mathrm{Cr}^{6+}$ & $1-3$ & Osasona et al. (2015) \\
Polyurethane-keratin hybrid membranes & $35 \%$ & $\mathrm{Cr}^{6+}$ & 7 & Saucedo et al. (2011) \\
Alkali-treated chicken feather & 90.91 & $\mathrm{Cr}^{6+}$ & 2 & Present work \\
\hline
\end{tabular}

Thermodynamic study suggests that biosorption of $\mathrm{Cr}(\mathrm{VI})$ onto chicken feather is endothermic in nature with very high Gibbs free energy at higher temperature. Therefore, it has been proven that RSM is a powerful statistical modeling techniques for evaluation and optimization of $\mathrm{Cr}(\mathrm{VI})$ biosorption from aqueous solutions.

Acknowledgements Authors are thankful to the all faculty of the Department of Environmental science, The University of Burdwan, Burdwan, West Bengal, India. Authors also extend their thanks to Dr Rajarshi Ghosh, Assistant Professor, Department of Chemistry, The University of Burdwan for providing FTIR facilities. Authors also take the opportunity from USIC Department, Burdwan University for SEM study.

\section{Compliance with ethical standards}

Conflict of interest Authors declared that they have no conflict of interest for publishing the present manuscript.
Open Access This article is distributed under the terms of the Creative Commons Attribution 4.0 International License (http://creativeco mmons.org/licenses/by/4.0/), which permits unrestricted use, distribution, and reproduction in any medium, provided you give appropriate credit to the original author(s) and the source, provide a link to the Creative Commons license, and indicate if changes were made.

\section{References}

Aguayo-Villarreal IA, Bonilla-Petriciolet A, Hernandex-Montoya V, Montes-Moran MA, Reynel-Avila HE (2011) Batch and column studies of $\mathrm{Zn}^{2+}$ removal from aqueous solution using chicken feathers as sorbents. Chem Eng J 167:67-76

Ahluwalia SS, Goyal D (2010) Removal of Cr(VI) from aqueous solution by fungal biomass. Eng Life Sci 10(5):480-485

Al-Aseh S, Banat F, Al-Rousan D (2003) Beneficial reuse of chicken feathers in removal of heavy metals from wastewater. J Cleaner Product 11:321-326

Alemu A, Leema B, Gabbiye N, Alula MT, Desta MT (2018) Removal of chromium(VI) from aqueous solutions using vesicular basalt: 
a potential low-cost wastewater treatment system. Heliyon 4:e00682. https://doi.org/10.2016/j.helion.18.e00682

Bai RT, Abraham E (2001) Biosorption of Cr(VI) from aqueous solution by Rhizopus nigricans. Bioresour Technol 79:73-81

Barrera-Diaz CE, Lugo-Lugo V (2012) A review of chemical, electrochemical and biological methods for aqueous $\mathrm{Cr}(\mathrm{VI})$ reduction. J Hazard Mater Bilyer B 223-224:1-12

Box GEP, Wilson KB (1951) On the experimental attainment of optimum conditions. J R Stat Soc 13:1-45

Chattoraj S, Mondal NK, Das B, Roy P, Sadhukhan B (2013) Biosorption of carbaryl from aqueous solution onto Pistia stratiotes biomass. Appl Water Sci. https://doi.org/10.1007/s1320 $1-013-0132-\mathrm{z}$

Chaudhary N, Balomajumder C (2014) Optimization study of adsorption parameters for removal of phenol on aluminium impregnated fly ash using response surface methodology. J Taiwan Inst Chem Eng 45:852-859

Chhikara S, Dhankhar R (2008) Biosorption of Cr(VI) from electroplating industrial effluent using immobilized Aspergillus biomass. J Environ Biol 29(5):773-778

Cojocaru C, Zakrzewska-Trznadel G (2007) Response surface modeling and optimization of copper removal from aqua solutions using polymer assisted ultrafiltration. J Membr Sci 298:56-70

Das B, Mondal NK, Roy P, Chattoraj S (2013) Application of response surface methodology for hexavalent chromium adsorption into alluvial soil of Indian Origin. Int J Environ Pollut Sol 2:72-87

de la Rosa G, Reynel-Avila HE, Bonilla-Petriciolet A, Cano-Rodríguez I, Velasco-Santos C, Martínez- Hernández AL (2008a) Recycling poultry feathers for $\mathrm{Pb}$ removal from wastewater: kinetic and equilibrium studies. Int J Chem Biol Eng 1(4):185-193

de la Rosa G, Reynel-Avila HE, Bonilla-Petriciolet A, Cano-Rodríguez I, Velasco-Santos C, Martínez-Hernández AL (2008b) Recycling poultry feathers for $\mathrm{Pb}$ removal from waste water: kinetic and equilibrium studies. Proc World Acad Sci Eng Technol 30:1011-1019

Dey U, Mondal NK (2016) Ultrastructural deformation of plant cell under heavy metal stress in Gram seedlings. Cogent Environ Sci 2:1196472. https://doi.org/10.1080/23311843.2016.1196472

Dong H, Denga J, Xiea Y, Zhanga C, Jianga Z, Chenga Y, Houa K, Zenga G (2017) Stabilization of nanoscale zero-valent iron (nZVI) with modified biochar for $\mathrm{Cr}(\mathrm{VI})$ removal from aqueous solution. J Hazard Mater 332:79-86

Enniyaa I, Rghiouib L, Jourania A (2018) Adsorption of hexavalent chromium in aqueous solution on activated carbon prepared from apple peels. Sustain Chem Pharma 7:9-16

Gao P, Liu Z, Wu X, Cao Z, Zhuang Y, Sun W, Xue G, Zhou M (2014) Biosorption of chromium(VI) ions by deposits produced from chicken feathers after soluble keratin extraction. CLEAN Soil Air Water 42(11):1558-1566

Gode F, Pehlivan E (2005) Removal of Cr(VI) from aqueous solution by two Lewatit anion exchange resins. J Hazards Mater 119:175-182

Gupta VK, Ali I (2004) Removal of lead and chromium from wastewater using bagasse fly ash-a sugar industry waste. J Colloid Interface Sci 271:321-328

Gupta S, Babu V (2009) Removal of toxic metal Cr(VI) from aqueous solutions using sawdust as adsorbent: equilibrium, kinetics and regeneration studies. Chem Eng J 150(2-3):352-365

Gupta R, Ahuja P, Khan S, Saxena RK, Mahapatra H (2000) Microbial biosorbents: meeting challenges of heavy metal pollution in aqueous solutions. Curr Sci 78:967-972

Gupta VK, Shrivastava AK, Jain N (2001) Biosorption of Cr(VI) from aqueous solutions by green algae Spirogyra sp. Water Resour 35:4079-4085
Han X, Wong YS, Wong MH, Tama NFY (2007) Biosorption and bioreduction of microalgal isolate chlorella miniata. J Hazard Mater 146:65-72

Jin X, Lu L, Wu H, Ke Q, Wang H (2013) Duck feather/nonwoven composite fabrics for removing metals present in textile dyeing effluents. J Eng Fibers Fabrics 8(3):89-96

Kan C-C, Ibe AH, Rivera KKP, Arazo RO (2017) Hexavalent chromium removal from aqueous solution by adsorbents synthesized from groundwater treatment residuals. Sustain Environ Res 27:1-9

Khambhaty Y, Mody K, Basw S, Jha B (2009) Biosorption of $\mathrm{Cr}(\mathrm{VI})$ onto marine Aspergillusniger: experimental studies and pseudo-second order kinetics. World J Microbial Biotechnol 25:1413-1421

Khosa MA, Ullah A, Wu J (2013) Chemical modification, characterization, and application of chicken feathers as novel biosorbents. RSC Adv 3:20800-20810

Kumar ASK, Kakan SS, Rajesh N (2013) A novel amine impregnated grapheme oxide adsorbent for the removal of hexavalent chromium. Chem Eng J 230:328-337

Kumari AR, Sobha K (2015a) Cost effective and ecofriendly methods for copper removal by adsorption with Emu Feather (Dromaius norachollandiae) and chitosan (Agaricus bisporus) composite. Int J Chem Technol Res 8(4):1769-1782

Kumari AR, Sobha K (2015b) Cost effective and ecofriendly method for copper removal by adsorption with Emu feather (Dromaius novaehollandiae) and Chitosan (Agaricus bioporus) composite. Int J ChemTech Res 8(4):1769-1782

Lunyera J, Smith SR (2017) Heavy metal nephropathy: considerations for exposure analysis. Int Soc Nephrol 92(3):548-550

Melay WJ, Reinhard FP (2000) Waste minimization and recovery technologies. Met Firishing 98:817-850

Mise SR, Rajamanya VS (2003) Adsorption studies of Cr(VI) on activated carbon derived from Sorghum vulgare (Dried stem of Jowar). Ind Environ Health 45:49-58

Mondal MK (2010) Removal of Pb(II) from aqueous solution by adsorption using activated tea waste. Korean J Chem Eng 27(1):144-151

Mondal NK, Samanta A, Dutta S, Chattoraj S (2017) Optimization of $\mathrm{Cr}(\mathrm{VI})$ biosorption onto Aspergillus niger using 3-level BoxBehnken design: equilibrium, kinetic, thermodynamic and regeneration studies. J Genet Eng Biotechnol 15(1):151-160

Montgomery DC (2001) Statistical quality control, 4th edn. Wiley, Hoboken, NJ

Osasona I, Adebayo AO, Okoronkwo AE, Ajayi OO (2015) Acid and alkali modified cow hoof powder as adsorbents for chromium(VI) as adsorbents for chromium(VI) removal from aqueous phase. Iran J Energy Environ 6(4):290-300

Park D, Yun YS, Park JM (2001) Removal of chromium with echonia biosorption. In: The 14th international biohydrometallurgy symptosium, Ouro Preto, Brazil, pp 513-520

Sadhukhan B, Mondal NK, Chattoraj S (2014) Biosorptive removal of cationic dye from aqueous system: a response surface methodological approach. Clean Technol Environ Policy 16:1015-1025

Saha R, Mukherjee K, Saha I, Ghosh A, Ghosh SK, Saha B (2013) Removal of hexavalent chromium from water by adsorption on mosambi (Citruslimetta) peel. Res Chem Intermed 39:2245-2257

Saucedo V, Martínez-Hernández AL, Martínez-barrera G, Castaño VM (2011) Removal of hexavalent chromium from water by polyurethane-keratin Hybrid Membranes. Water Air Soil Pollut 218(1):557-571

Sayed SA, Saleh SM, Hasan EE (2005) Removal of some polluting metals from industrial water using chicken feathers. Desalination 181:243-255

Sekimoto Y, Okiharu T, Nakajima H, Fujii T, ShiraiK Moriwaki $\mathrm{H}$ (2013) Removal of $\mathrm{Pb}(\mathrm{II})$ from water using keratin 
colloidal solution obtained from wool. Environ Sci Pollut Res 20(9):6531-6538

Shi S, Yang J, Liang S, Li M, Gan Q, Xiao K, Hu J (2018) Enhanced $\mathrm{Cr}(\mathrm{VI})$ removal from acidic solutions using biochar modified by $\mathrm{Fe}_{3} \mathrm{O}_{4} @ \mathrm{SiO}_{2}-\mathrm{NH}_{2}$ particles. Sci Total Environ 628-629:499-508

Srividya K, Mohanty K (2009) Biosorption of hexavalent chromium from aqueous solution by Catla catla scales: equilibrium and kinetics studies. Chem Eng J155:666-673

Sun P, Liu Z-T, Liu Z-W (2009a) Chemically modified chicken feather as sorbent for removing toxic chromium(VI) ions. Ind Eng Chem Res 48(14):6882-6889

Sun P, Liu ZT, Liu ZT (2009b) Chemically modified chicken feather as sorbent for removing toxic chromium(VI) ions. Indus Eng Chem Res 48(14):6882-6889

Tachibana A, Furuta Y, Takeshima H, Tanabe T, Yamauchi K (2002) Fabication of wool Keratin Spouge Sealffolds for long term cell cultivation. J Biotechnol 93(2):165-170

Tanabe T, Oxitsu N, Technibana A, Yamanchi K (2002) Preparation and characterization of keratin-chitosan composite film. Biomaterials 23(3):817-825

Tran CD, Mututuvari TM (2015) Cellulose, chitosen and keratin composite materials. Controlled drug release. Langmuir 31(4):1516-1526
Wang XS, Tmg YP, Tao SR (2008) Removal of Cr(VI) from aqueous solutions by the nonliving biomass of alligator weed: kinetics and equilibrium. Adsorption 14:823-830

Wang T, Zhang I, Li C, Yang W, Song T, Tang C, Meng Y, Dai S, Wang $\mathrm{H}$, Chai I, Luo J (2015) Synthesis of core-shell magnetic $\mathrm{Fe}_{3} \mathrm{O}_{4} @$ poly(m-Phenylenediamine) particles for chromium reduction and adsorption. Environ Sci Technol 49:5654-5662

Zhang H, Carrillo F, López-Mesas M, Palet C (2018) Valorization of keratin biofibers for removing heavy metals from aqueous solutions. Textstyle Res J. https://doi.org/10.1177/0040517518764008

Zulkali MMD, Ahmad AL, Norulakmal NH (2006) Oryaza stiva L. husk as heavy metal adsorbent: optimization with lead a s model solution. Bioresour Technol 97:21-25

Publisher's Note Springer Nature remains neutral with regard to jurisdictional claims in published maps and institutional affiliations. 